NBER WORKING PAPER SERIES

\title{
WHY ISN'T MEXICO RICH?
}

\author{
Gordon H. Hanson
}

Working Paper 16470

http://www.nber.org/papers/w16470

\author{
NATIONAL BUREAU OF ECONOMIC RESEARCH \\ 1050 Massachusetts Avenue \\ Cambridge, MA 02138 \\ October 2010
}

Thanks to Daniel Chiquiar, Eduardo Engel, Roger Gordon, and Santiago Levy for helpful comments and suggestions. The views expressed herein are those of the author and do not necessarily reflect the views of the National Bureau of Economic Research.

NBER working papers are circulated for discussion and comment purposes. They have not been peerreviewed or been subject to the review by the NBER Board of Directors that accompanies official NBER publications.

(C) 2010 by Gordon H. Hanson. All rights reserved. Short sections of text, not to exceed two paragraphs, may be quoted without explicit permission provided that full credit, including $\bigcirc$ notice, is given to the source. 
Why Isn't Mexico Rich?

Gordon H. Hanson

NBER Working Paper No. 16470

October 2010

JEL No. F1,O4

\begin{abstract}
$\underline{\text { ABSTRACT }}$
Over the last three decades, Mexico has aggressively reformed its economy, opening to foreign trade and investment, achieving fiscal discipline, and privatizing state owned enterprises. Despite these efforts, the country's economic growth has been lackluster, trailing that of many other developing nations. In this paper, I review arguments for why Mexico hasn't sustained higher rates of economic growth. The most prominent suggest that some combination of poorly functioning credit markets, distortions in the supply of non-traded inputs, and perverse incentives for informality creates a drag on productivity growth. These are factors internal to Mexico. One possible external factor is that the country has the bad luck of exporting goods that China sells, rather than goods that China buys. I assess evidence from recent literature on these arguments and suggest directions for future research.
\end{abstract}

\author{
Gordon H. Hanson \\ IR/PS 0519 \\ University of California, San Diego \\ 9500 Gilman Drive \\ La Jolla, CA 92093-0519 \\ and NBER \\ gohanson@ucsd.edu
}




\section{Introduction}

In 1994, Mexico joined the Organization for Economic Cooperation and Development. Its admission, at the time unusual for a club of primarily rich nations, was recognition from OECD members that the country was on the road to success. After a sovereign default in 1982, which precipitated a currency collapse and sharp contraction in GDP, Mexico was forced to make significant changes in its economy. Presaging reform efforts elsewhere in Latin America and a decade later in Eastern Europe, the country proceeded aggressively to reduce the role of the state in the economy and to embrace global markets.

Mexico’s approach was nothing if not ambitious. After its default, it faced a difficult macroeconomic stabilization, from which it emerged with an independent central bank and more developed financial markets (Aspe, 1993). Concomitantly, the country liberalized foreign trade and investment, first unilaterally, by acceding to the General Agreement on Trade and Tariffs, and later regionally, through the North American Free Trade Agreement. In the span of a few years, it privatized a disparate collection of nearly 1,000 state-owned enterprises, including the

communications behemoth, Teléfonos de México (Telmex), and the country’s banks, which had been nationalized in a failed effort to impede capital outflows leading up to the 1982 crisis (Lustig, 1998). By 1994, the year NAFTA was implemented, Mexico’s transformation seemed complete. Under the guidance of three successive technocratic governments, in which $\mathrm{PhD}$ economists trained at US universities managed economic policy, the country had become a prime exemplar of the Washington Consensus (Kuczynksi and Williamson, 2003).

All that was missing was economic growth. Alas, the growth never came. Mexico succeeded in lowering inflation, maintaining fiscal discipline, reducing its external debt burden, and increasing trade as a share of GDP. But its growth has been lackluster. Figure 1 plots log 
per capita GDP in Mexico against a set of comparison countries roughly similar in population and initial income. Within Latin America, Mexico has kept pace with Argentina, but not Chile or, more recently, Brazil (panel a). Its growth is well below Southeast Asia (panel b) and Eastern and Central Europe (panel c). Between 1985 and 2008, Mexico managed an annual average growth rate in per capita GDP of just 1.1\%, lower than all of the comparison countries except Venezuela (0.8\%). Given the vigor of its reforms, it is hard not to sense that Mexico has underachieved (Ortiz, 2003). Managing to best only Venezuela, with its ongoing domestic economic and political turmoil, is hardly the future the country had envisioned. In 2006, it was in part disillusionment with the economy that brought Mexico within a hair's breadth of electing a populist president who campaigned on reversing earlier liberalizations.

In this paper, I review arguments for why Mexico hasn't sustained higher rates of economic growth. Much has been made of development disappointments in lower income countries (e.g., Easterly, 2002; Stiglitz, 2003). The 1990s, during which Latin America suffered from continued macroeconomic instability and a severe financial crisis rocked Asia, appeared to belie the promise of market-oriented economic reform. However, in the 2000s such concerns receded, as the expansion of China and India, among other emerging nations, created a surge in global trade and contributed to broad-based income growth in export-oriented economies (Hanson, 2010). Though the recent global recession brought a severe contraction in world imports in 2008 and 2009, robust trade growth has now resumed.

In the 2000s trade boom, Mexico again seemed to miss out. Between 2001 and 2008, while the other comparison countries managed annual growth rates of $2.3 \%$ or higher, Mexico was stuck at 1.3\% (Table 1). After three decades of sluggishness, the country's growth record looks idiosyncratic, reflecting deep structural impediments rather than short term problems, such 
as real exchange rate overvaluation, which appeared responsible for the country's weak performance in the early 1990s (Dornbusch and Werner, 1994). Recent literature provides a host of explanations for Mexico's laggard status. ${ }^{1}$ The most prominent suggest that some combination of poorly functioning credit markets, distortions in the supply of non-traded inputs, or perverse incentives for informality creates a drag on productivity growth. These are factors internal to Mexico. One possible external factor is that Mexico has the bad luck of exporting goods that China sells, rather than goods that China buys, meaning that China's expansion has put downward pressure on Mexico's terms of trade. Clearly, none of these mechanisms is unique to Mexico. For one or more of them to be able to explain Mexico's growth record, they must afflict the country in a particularly severe manner.

Before examining the arguments for Mexico's stagnation, it is worth reviewing common explanations for slow growth that are insufficient to explain the Mexican case. Because some countries in Latin America have done well in the last decade, Mexico's performance does not appear to be solely attributable to the region-wide institutional deficiencies that are often blamed for the hemisphere's slow development. These include a legacy of Spanish and Portuguese colonialism, high levels of wealth inequality, and factor endowments that facilitated the early emergence of a landed elite (e.g., Sokoloff and Engerman, 2000; Edwards, Esquivel, and Marquez, 2007; Edwards, 2009). The gap between average income in the United States and Latin America first manifested itself in the $18^{\text {th }}$ century and later widened in the $19^{\text {th }}$ and $20^{\text {th }}$ centuries. Between 1950 and 2001, there was zero convergence between Latin America and the US in per capita GDP. Latin America's decline relative to Asia and Europe, which during the

\footnotetext{
${ }^{1}$ For more in depth summaries of Mexico's growth performance and possible explanations see Lustig (1998), which focuses on macroeconomic stabilization and the absence of growth in the immediate aftermath of economic reforms; the volumes in Levy and Walton (2009), which address the political economy of economic growth in Mexico; and Chiquiar and Ramos-Francia (2009) and Aria, Azuara, Bernal, Heckman, and Villareal (2010), which examine the microeconomic foundations of Mexico's low productivity growth.
} 
second half of the $20^{\text {th }}$ century did converge toward US income levels, was due primarily to TFP. The region has long been plagued by disappointingly low productivity growth (Cole, Ohanian, Riascos, and Schmitz, Jr., 2005). Latin America’s common history is surely important for understanding many aspects of its economic development. Yet, in recent decades the region has not moved in lock step. Chile has performed decently since the late 1980s and Brazil, Colombia, and Peru have since 2000. Mexico, despite its market friendly reforms, has not joined the group, with its performance closer to Argentina and Venezuela, the region's black sheep in terms of economic policy. Its story must, then, have plot lines distinct from other Latin nations.

In low income countries, Collier (2007) identifies common pitfalls that contribute to poverty traps. None apply to Mexico, itself a middle income nation. For the last 80 years, Mexico has avoided military and political conflict, which enveloped the country in the early $20^{\text {th }}$ century. Indeed, after the 1982-1994 period of intensive economic reform, the country ended seven decades of single party rule and transitioned to a functioning if combative democracy. There has been a recent upsurge in violence associated with drug trafficking, but intense conflict did not emerge until 2006, too late to account for Mexico’s sluggishness. ${ }^{2}$ Despite being an oil exporter, the resource curse does not seem to have hit Mexico. Oil as a share of exports peaked in 1982 at 77\% and has declined steadily since, falling below 40 percent by 1988 and below 15 percent by 1993. In 2009, oil accounted for just 13\% of Mexico's total exports. Over the last two decades, Mexico's trade growth has been heavily concentrated in manufacturing (MorenoBrid, Santamaria, and Rivas Valdivia, 2005). If anything, Mexico has invested too little in petroleum exploration and production, partly as a consequence of constitutional limitations on foreign investment in the sector (Manzano and Monaldi, 2008). And Mexico cannot be said to

\footnotetext{
${ }^{2}$ The growth of the drug trade may distort GDP figures for Mexico. It is likely that value added in cultivating and exporting marijuana and opium, manufacturing and exporting methamphetamine, and distributing cocaine from South America to the United States is not fully represented in the country's national income accounts.
} 
suffer from residing in a poor neighborhood. NAFTA affords the country access to two nearby large, rich markets. In 2009, Mexico's exports to the US as a share of its total foreign shipments were $81 \%$. Mexico’s problems, it seems, lie elsewhere.

\section{Faulty Provision of Credit}

The provision of credit is central to the process of economic development (Rajan and Zingales, 1998). Without mechanisms that move savings from lenders to borrowers, a country has poor prospects for taking advantage of productive investment opportunities. Mexico stands out for channeling low levels of private credit to firms or households. Over the period 20012008, domestic credit to the private sector as a share of GDP averaged 18\% in Mexico, lower than all comparison countries except Argentina and Venezuela (Table 2). A growing body of literature cites the weakness of Mexico's credit markets as an important factor behind the country's low productivity growth.

Poorly developed financial markets have plagued Mexico since its independence from Spain (Haber, 1991). One problem has been risk of expropriation. In the last 40 years, the government has expropriated the assets of private banks twice (Haber, 2005). The first episode was a de facto nationalization that occurred in the mid 1970s, when the government increased the reserves banks were required to hold in the central bank to over 40 percent and paid an interest rate on these deposits that trailed the rate of inflation. The second expropriation was an explicit bank nationalization in 1982, which occurred in the midst of Mexico's sovereign default. Another problem has been poor oversight of bank lending. Shortly after Mexico's banks were privatized in 1991, credit provision spiked. Haber (2005) argues that in Mexico’s haste to privatize its banks it failed to establish mechanisms that would impede the abuse of deposit 
insurance or lending to bank directors or other insiders. Consequently, bank credit expanded rapidly, financed in part by interbank lending, which the government insured. Rapidly accumulating non-performing loans and the 1994 peso collapse contributed to widespread bank failures. ${ }^{3}$ The government was later obligated to recapitalize the banking system.

Since the 1994-1995 banking crisis, Mexico has overhauled its financial regulations. It has modernized accounting standards, permitted foreign ownership of banks, set reserves according to the riskiness of bank loan portfolios, modified deposit insurance, and sought to prevent insider lending. While bankruptcy provisions were also modified, Haber (2005) suggests that these reforms primarily affected easily collateralizable loans, such as for autos or homes, but did little to spur commercial lending. As a result, the difficulty lenders have in seizing assets from borrowers continues to hinder credit provision. In the 2004 World Bank Doing Business Indicators, Mexico scored a 0 out of 4 in protections provided to creditors, putting it among just 11 countries (out of 132) in the lowest category. In Table 2, one sees that despite Mexico’s reforms domestic credit to the private sector actually declined from the 1990s to the 2000s, with its performance relative to comparison countries showing no improvement. ${ }^{4}$

Turning to how credit markets affect growth, Bergoeing, Kehoe, Kehoe, and Soto (2002) suggest that Mexico’s bankruptcy laws account for Mexico’s poor performance relative to Chile. Beginning in the 1970s, both countries suffered government debt crises and bouts of high inflation which they addressed by imposing fiscal austerity and monetary restraint. Each

\footnotetext{
${ }^{3}$ Tornell, Westermann, and Martinez (2004) suggest that because the credit crunch was accompanied by a significant real exchange rate depreciation the non-traded sector was hit particularly hard, with the contraction in non-tradables ultimately creating bottlenecks in the supply of inputs that inhibited export growth.

${ }^{4}$ Chiquiar and Ramos-Francia (2009) and Haber (2009) suggest that while these reforms did not appreciably lower interest rates to borrowers they did lead to greater concentration in the banking sector and to higher profit margins (both in absolute terms and relative to a comparison group of 12 other countries, among which only Brazil and Peru had higher bank profitability). Mexico's government competition commission, out of concern that the country's banking system is imperfectly competitive, has ruled that Mexico's banks should make their services more transparent and reduce costs to consumers of switching banks. It has also moved to lower bank entry barriers.
} 
liberalized trade and privatized state owned companies. Subsequently, Chile enjoyed high productivity and income growth while Mexico did not. Provisions for seizing assets of borrowers in default are an important remaining difference between the two nations. Chile's laws are relatively favorable toward lenders. Through process of elimination, Bergoeing et al. (2002) conclude that the differences in bankruptcy laws are the most likely explanation for Chile’s superior performance. While differences in bankruptcy provisions are certainly a plausible explanation for the two countries' divergence, the evidence is circumstantial. Bergoeing et al. (2002) make a convincing case that differences in fiscal or trade policy cannot account for Chile's relative success, but a host of other factors, including those mentioned below, remain outside consideration. Additionally, Bergoeing et al. (2002) argue that Chile and Mexico privatized state-owned companies to a comparable degree. But other literature (e.g., Levy and Walton, 2009) suggests that it is how Mexico privatized its companies that matters, in particular the country's failure to prevent the formation of private monopolies.

For credit markets to be a factor in Mexico's low growth rates, they must affect productivity. To gauge the extent of barriers to investment in Mexico, McKenzie and Woodruff (2008) conducted an experiment in which they randomized the provision of cash grants to small retail firms in Mexico, the results from which allow them to estimate the marginal rate of return to investment. They find that rates of return to capital are $20 \%$ to $32 \%$ per month, which were three to five times market interest rates during the sample period. Rates of return are highest among firms that report being financially constrained (but, surprisingly, also remain above market rates for firms that do not report being constrained). Their results suggest that there are imperfections in Mexico's financial markets, which impede the flow of credit to profitable undertakings, particularly for small scale entrepreneurs. Other evidence, some experimental and 
some not, suggests that in Ghana, India, Kenya, and Sri Lanka rates of return to capital in small scale enterprises are also well above market rates (see discussion in McKenzie and Woodruff, 2008), implying that Mexico’s situation is not unique.

Could weak protections for creditors be responsible for limited access to credit in Mexico? In the United States, Gropp, Scholz, and White (1997) find that in states that provide higher personal exemptions for debtors in bankruptcy, which limits the assets that creditors can seize, a lower fraction of credit is held by low-asset households, suggesting that weak creditor protections divert lending away from relatively poor borrowers. Yet, diverting credit away from the poor, while a concern for poverty alleviation, does not necessarily translate into diminished productivity growth. Fan and White (2003) find that higher exemptions for personal bankruptcy in US states operate as a form of wealth insurance, which increases the level of entrepreneurship, even as high risk borrowers are cut off from loans. ${ }^{5}$

How important, then, are Mexico’s credit problems in explaining its growth performance? Based on a survey of 4,000 firms in 54 countries during the late 1990s, Beck, Demirguc-Kunt, and Maksimovic (2005) report that the fraction of firms saying they face severe obstacles in obtaining finance is highest in Mexico. Their work also finds that firm sales growth is lower in countries that have greater obstacles in obtaining financing, measured in terms of collateral requirements, bank paperwork, or interest rates. These findings, while intriguing, represent indirect evidence on economic growth, as they relate to firm sales and not productivity and do not account for why financial policies vary across countries.

One could imagine two approaches to estimate the impact of bankruptcy provisions on

\footnotetext{
${ }^{5}$ For firms in the informal sector, the incentives for entrepreneurship from generous bankruptcy provisions may be undermined by other aspects of the tax code. Informal entrepreneurs, by virtue of their tax status, reap no tax savings from losses to income or capital. However, they may only be able to realize substantial gains to income or capital by shifting into the formal sector, which brings with it an increase in tax liabilities. The asymmetric treatment of gains and losses may be a disincentive to innovation among informal enterprises.
} 
productivity growth in Mexico. One would be a cross country approach, similar to Beck, Demirguc-Kunt, and Maksimovic (2005) but extended over longer time period, in which one regressed firm or industry growth in productivity on measures of creditor protection, exploiting cross country and cross time variation in bankruptcy provisions. The obvious problem with such regressions is that in order for them to be well identified one would have to find sources of exogenous variation in countries' financial provisions, which could be difficult. A second approach would be for Mexico itself to experiment with changing its bankruptcy provisions, perhaps by varying the timing of adjustments in protections to creditors across states within the country. One could then estimate how firm, industry, or regional outcomes change in response to the policy change. Such an experiment would clearly be a significant undertaking, but given the low apparent return to Mexico from its extensive financial reforms to date the benefits from identifying which features of credit markets continue to inhibit growth may yield commensurately large returns.

\section{Social policy and informality}

The size of the informal sector in Latin America is frequently cited as a drag on economic development. Aside from de Soto’s (1989) so-called romantic perspective, in which informal firms are a vibrant and underappreciated part of the productive economy, many commentators see informality as the result of firms remaining small in order to avoid onerous government regulations (La Porta and Schleifer, 2008). Informality keeps firms in existence that would be forced to exit, either because of poor management or outdated technology, if they had to compete for inputs with formal sector firms on a level playing field. One consequence of informality is, therefore, the survival of small, unproductive enterprises. The dispersion in productivity across 
plants in Mexico is much higher than in the United States. In 2004, 36\% of manufacturing employment in Mexico was in establishments with fewer than 50 workers and 22\% was in establishments with fewer than 10 workers. Enterprises with under 10 employees tend to have very low TFP (Pages, 2010), with 91\% of these plants having productivity levels below their industry average. The majority of these micro-enterprises are informal.

Hsieh and Klenow (2009) use micro data on Mexican non-agricultural establishments to examine how aggregate TFP in the country would change were productivity equalized across establishments by moving factors toward more productive plants, while accounting for endogenous changes in productivity at the plant level. Based on data for 1999 and 2004, they estimate that such a reallocation would raise TFP in Mexico by $100 \%$ in the manufacturing sector and by $250 \%-300 \%$ in non-manufacturing. The aggregate productivity gain from factor reallocation for Mexico is, interestingly, comparable to that for China but 1.5 to 2 times larger than for Argentina, Bolivia, Chile, Colombia, Ecuador, or Uruguay.

For these counterfactual exercises to be meaningful, there must be distortions in the economy that prevent factor reallocation from occurring naturally. Hsieh and Klenow find that TFP is higher in firms that make payments into Mexico’s social security system, which is Levy’s (2008) preferred definition of formality, suggesting that evasion of payroll taxes is among the distortions contributing to productivity dispersion. Formal sector firms make contributions to social security equal to $18 \%$ of the total wagebill. Hsieh and Klenow estimate that reallocating factors to establishments that pay into social security would raise aggregate productivity by $19 \%$ in manufacturing, or one fifth of the total productivity gain from factor reallocation, implying informality is an important source of cross-plant differences in TFP.

Levy (2008) makes an explicit argument for how informality affects productivity in 
Mexico. The starting point for his critique is Mexico’s dual system of social insurance. One system governs the formal economy, in which workers and employers are subject to obligatory payroll taxes that cover social security benefits, including retirement pensions, health care, disability and life insurance, child care, and housing loans. Formal sector employment is also subject to regulations that govern firing and severance pay. A second system of social insurance covers the workers that Levy defines as informal, including illegally employed salaried workers (i.e., workers that by law should be enrolled in social security but are not), workers paid on commission, the self employed, and unpaid workers. These individuals have the option of participating in social protection programs, subject to a nominal contribution, which provide health care, retirement pensions, housing subsidies, child care, and life insurance. Importantly, the participation of informal workers in social protection programs is voluntary and a la carte, allowing individuals to select into the specific programs which suite their needs. Formal workers, whose contributions to social security are mandatory, have no such option. Further, the monetary contributions of informal workers do not cover the full cost of social protection programs, with the difference met in part by consumption taxes.

In theory, the tax on formal sector employment and the subsidy to informal sector employment results in a relatively low (high) marginal productivity of labor in the informal (formal) sector, creating static inefficiency and depressing aggregate TFP. Empirical evidence, as seen, is consistent with such outcomes. Additionally, informality may have negative dynamic effects on productivity, and therefore growth, if keeping wages of formal establishments artificially high reallocates investment toward lower productivity informal firms. In Mexico it appears that the returns to labor market experience are lower in informal than in formal employment, which may indicate that informality suppresses the accumulation of human capital 
(Arias, Asuara, Bernal, Heckman, and Villarreal, 2010). While the theoretical linkages between informality and growth are clear, making the empirical connection is more problematic. Informality appears to result in a lower level of TFP but does it suppress TFP growth? In Mexico's case, one would want to know whether raising the benefits to informal workers through social protection programs (financed by consumption taxes) lowers the growth rate. Research has yet to provide a definitive answer to this question.

What research has examined is whether the recent expansions of social protection programs available to informal workers have reallocated employment toward the informal sector. The aggregate data show no upward trend in informality (Arias, Asuara, Bernal, Heckman, and Villarreal, 2010). Between 1995 and 2009, the fraction of workers employed outside of the social security system in Mexico actually declined, from 66\% to 62\%, though informality did rise among urban workers. Among the different categories of informal workers, only the share of illegal salaried labor in employment has increased over time. The employment share of selfemployed workers has been stable and the share for workers paid on commission has fallen.

In micro-level analysis of whether Mexico's dual system of social insurance has increased informality, Barros (2008) exploits regional variation in the timing of the role out of Seguro Popular, a large health insurance program available to workers who are not covered by social security which is the centerpiece of Mexico's new system of social protection. The program amounted to a substantial increase in the quality and quantity of health insurance to qualifying individuals, who account for roughly half the population, forcing the government to phase in the program gradually. The timing of the roll out favored small states and states not in control of the main opposition political party. Barros finds that in repeated cross section data the probability a household head works in the informal sector is uncorrelated with the government 
projected enrollment intensity of Seguro Popular (i.e., the planned enrollment in a state in a given year based on the roll out strategy), meaning that individuals in states exposed to earlier roll out of Seguro Popular were not more likely to be employed informally. Because program intensity is not random, the results are hard to interpret. The estimation strategy would underestimate the effect of Seguro Popular on informality if the planned roll out of the program was more rapid in states subject to shocks that disfavor formality.

Knox (2008) addresses similar questions using panel data on 800 families, exploiting temporal variation in which families were eligible for Seguro Popular (thus allowing her to control for household fixed effects in informal status). Becoming eligible for the program increases labor force participation, which implies an increase in employment in the informal sector given that eligible households are those that do not qualify for social security. Juarez (2008) focuses on the roll out of a free health care program in Mexico City, finding that for females (in salaried employment with no more than 12 years of education) expanded health benefits reduces the likelihood of being employed formally (i.e., being covered by social security). Though the literature is still young, there is some evidence that expanded health insurance for informal workers increases employment in the informal sector.

The level of TFP in informal establishments in Mexico is low relative to formal plants. Mexico’s social protection programs may be raising the incentive for informality, possibly hindering growth. However, the newness of these programs suggests they cannot account for Mexico’s poor growth performance prior to the late 1990s. Social protection programs for the poor in Mexico have accommodated informality, thereby contributing to its persistence, but cannot explain the origins of informality in Mexico or why the growth effects of informality in the country would be worse than elsewhere in Latin America. 


\section{Too little regulation (or too much)}

In comparing production costs across countries, Mexico stands out for having high prices for electricity, high prices for telecommunications services, expensive and spotty internet services, and a scarcity of skilled labor. In each of these input markets, specific interest groups are blamed either for impeding the government from enforcing anti-monopoly regulations or for convincing the government to regulate markets in a way that preserves their capacity to earn rents (Levy and Walton, 2009). While I discuss just three input markets, these arguments have been applied to other sectors of Mexico’s economy, as well (see Guerrero, Lopez-Calva, and Walton, 2009). While unfavorable conditions in Mexico's input markets are well documented, it is less clear whether they can account for Mexico's poor relative growth.

The most maligned industrialist in Mexico is perhaps Carlos Slim, the world's richest person and the largest shareholder in Telmex, Mexico's telecommunications giant. Slim is blamed for using his acquisition of Telmex from the government first to establish and later to protect monopoly power in markets for landline telephone services, mobile telephony, and internet access. In data for 2006-2008, Mexico compares poorly to other countries in the costs of its telecom services. Among a group of developing and developed nations, ${ }^{6}$ it has the highest levels of single-firm concentration in fixed and mobile telephone industries (with Telmex controlling over 90 percent in the former and over 70 percent in the latter), the highest costs of fixed line business telephone services (which are two and half times the level in the United States), and the lowest number of broadband internet subscribes per capita (Chiquiar and RamosFrancia, 2009). While it is plausible that Telmex's dominant market position allows it to earn

\footnotetext{
${ }^{66}$ The comparison countries are Brazil, Canada, Chile, China, Colombia, the Czech Republic, EU nations, Hungary, Japan, Korea, New Zealand, Poland, the Slovak Republic, Turkey, and the United States.
} 
supra-normal profits, it is unclear whether such an outcome matters for Mexico's growth rate.

The argument would have to be that high prices for telecom services depress capital

accumulation or innovation. A causal link between the price and availability of

telecommunications services and economic growth has yet to be established.

Surprising as it may seem for a country that exports oil, Mexico has relatively high prices for electricity. Since 2000, electricity prices per kilowatt hour in Mexico have exceeded those in the United States by 1.1 to 1.7 times. Among comparison countries, Mexico has the highest rate of energy loss, measured as energy produced but not paid for as a percentage of total energy handled (Chiquiar and Ramos-Francia, 2009). Electricity production in Mexico is the sole provenance of two state owned companies, which have historically had strong labor unions. The proximate causes for Mexico’s high costs and low quality in electricity generation include reliance on oil based production, low labor productivity, and high wages for electricity workers, who are among the most highly paid workers in the country and whose average wage rates are over three times the average for formal sector workers. Holding output constant, were electricity generation in Mexico to operate with the same labor productivity as in Chile, Mexico would have $62 \%$ fewer workers in the sector. As with telecommunications services, high electricity prices raise production costs relative to other countries. Again, however, it is unclear how the price of electricity affects the rate of economic growth.

An input market whose functioning does have well established effects on growth is the supply of skilled labor. If Mexico’s public schools or labor market regulations somehow reduce the incentive to attain education, then Mexico may have lower growth rates, resulting either from a reduced supply of innovation-producing scientists and engineers (e.g., Jones, 1995) or from missing out on positive externalities in the accumulation of human capital (e.g., Lucas, 1988). In 
2007, only 50\% of Mexicans 15-19 years old were enrolled in public or private educational institutions, slightly above levels for Turkey but $20 \%$ to $42 \%$ below Brazil, Chile, Estonia, Hungary, Korea, Portugal, the Slovak Republic, and Slovenia (Arias et al., 2010). Mexico’s poor education performance may be attributable to the capture of its education system by powerful labor unions. Close to $90 \%$ of public education expenditure in Mexico is on compensation of staff, leaving little left over for buildings, computers, or other educational infrastructure. However, other countries in Latin America also have unionized public education, which raises the question of why Mexico's would have consequences that are more deleterious for growth. Mexico's labor unions have strongly opposed linking teacher pay to student performance but this hardly makes them unique.

Beyond rates of tertiary education, Mexican students perform poorly in standardized tests relative to students in other nations at roughly similar income levels. Combining PISA scores for math, reading and science, Mexico does worse than all developing countries except Brazil, scoring well below Chile, the Czech Republic, Estonia, Hungary, Korea, Poland, Russia, and the Slovak Republic, both in absolute terms and relative to what one would predict based on expenditure per student in the country (Arias et al., 2010). Pritchett and Viarengo (2009) suggest that what may matter for country's economic development is not the average performance of students but the number of high achievers. Here again, Mexico's does not compare well. A PISA score of 625 qualifies a student as advanced. Only $0.3 \%$ of Mexican students attain a score of 625 or higher, relative to 18\% in Korea, 9\% in the Slovak Republic, and $2 \%$ in Thailand. If such high achievers are used intensively in developing or applying new technology, Mexico may face supply constraints in $R \& D$ relative to other countries.

Another factor potentially affecting Mexico's supply of skilled labor is emigration to the 
United States. As of 2008, there were 11.4 million individuals born in Mexico residing in the US, equal to $9.5 \%$ of the total Mexico born population (defined as the sum of Mexico born individuals in Mexico and the United States). Emigrants are overrepresented among the young. In 2000, $18 \%$ of Mexico born men aged 16 to 25 were residing in the United States, compared to $9 \%$ of 46 to 55 year olds. However, the skill profile of emigrants differs only modestly from individuals that remain in Mexico. Chiquiar and Hanson (2005) compare the earnings of nonmigrants in Mexico with the earnings that emigrants would earn were they to return to the country and be paid according to prevailing wage patterns. Emigrant men are drawn disproportionately from the middle of Mexico's wage distribution, whereas emigrant women are modestly positively selected. These results are based on 1990 and 2000 censuses for Mexico and the United States, in which one might be concerned about the undercount of illegal immigrants. Kaestner and Malamud (2010) largely replicate Chiquiar's and Hanson’s findings using the Mexican Family Life Survey, which tracks individuals in Mexico over time, including those that migrate to the US, whether legally or illegally.

We know little about how emigration affects skill or capital accumulation in Mexico. Higher emigration puts upward pressure on Mexican wages (Mishra, 2007: Aydemir and Borjas, 2007), reducing the incentive for capital inflows. Since the majority of Mexican migrants enter the United States illegally (Hanson, 2006), they may perceive weak incentives to continue their education beyond secondary school. Thus, emigration may be contributing to Mexico’s observed low rates of school attendance among 15 to 19 year olds. In rural Mexico, McKenzie and Rapoport (2010 find that the likelihood of completing secondary school or beginning high school is lower for youths in households that have sent migrants abroad.

While we see that Mexico produces few highly educated students relative to other 
countries, the literature has yet to explain why or quantify the implications of this fact for economic growth. Garcia-Verdu (2007) estimates that rising educational attainment specifically, the decline in the share of workers with no schooling or primary schooling and in the increase in the share with secondary or tertiary schooling - accounts for 74\% of Mexico’s GDP growth over 1988-1994 and 65\% over 1995-2005. However, aggregate TFP growth was negative in both time periods. If educational attainment was rising, why was TFP declining? This question cannot be answered in a standard growth accounting framework, in which TFP growth is taken as given. Obvious directions for future research are to examine the link between schooling, academic performance, emigration, and TFP levels and growth rates in Mexico.

\section{The perils of competing with China}

In the 1980s, as Mexico embarked upon a strategy of export-led development it sought to emulate the successful industrializers of East Asia. Then President Carlos Salinas cited Korea, in particular, as a model for Mexico, with hopes that the country would create its own chaebol Korea’s large industrial groups characterized by vertical integration in production, horizontal differentiation in output, and rapid export growth - to lead the country into the global economy. The reality turned out to be far different. Exports have grown dramatically in Mexico, rising from $12 \%$ of GDP in 1982 to $28 \%$ in 2008 . However, it is not large, vertically integrated firms that export the bulk of Mexico’s goods. Instead, nearly half of the country’s manufacturing exports and over 20 percent of its manufacturing value added (as of 2006) are produced by maquiladoras, or export assembly plants, which import inputs from abroad, primarily the United States, assemble or process the inputs into final outputs, and then export the finished goods, again primarily to the US (Bergin, Feenstra, and Hanson, 2010). Hong Kong and Taiwan also 
began their industrial development with heavy reliance on export assembly. Their firms later graduated into original-equipment manufacture and own-brand production, which involves greater in-house fabrication of inputs and design of outputs (Enright, Scott, and Dodwell, 1997). Mexico has not made such a transition. While the country has progressed from assembling apparel to assembling electronics and auto parts, it remains specialized in the labor-intensive processing of inputs for the US economy.

Mexico's failure to graduate from export assembly has left it exposed to competition from China, whose abundance in low skilled labor has given it a strong comparative advantage in labor-intensive manufacturing. By the late 1990s, export processing plants in China, which are similar to Mexico's maquiladoras, accounted for over half of the country's manufacturing exports (Feenstra and Hanson, 2005). For Mexico, China's growth is more threatening than it is for other countries in Latin America. Other large Latin nations tend to export the minerals, agricultural goods, and other commodities that China imports. In Mexico, as already mentioned, petroleum now accounts for less than 15 percent of exports. For better or worse, Mexico's fortunes in the global economy are tied to manufacturing. Over the period 2000-2005, manufacturing accounted for $88 \%$ of exports in China and $83 \%$ in Mexico, but only $54 \%$ in Brazil, 34\% in Colombia, 20\% in Peru, and 16\% in Chile.

Figure 2 shows that over the period 1991 to 2007, China’s share of US manufacturing imports rose steadily, whereas Mexico's share rose through the 1990s and then begin to decline. For both countries, there is an inflection point in 2001, at which time China's increase in US market share accelerated and Mexico changed from having a rising share to a declining one. The significance of 2001 is that this year marks China's accession to the World Trade Organization, giving it most favored nation status among WTO members. It is plausible that China's joining 
the WTO helped it to capture foreign market share from Mexico (see, e.g., Brambilla, Khandelwal, and Schott, 2010, on the apparel and textile industries).

The challenge of China's export growth for Mexico is that the two countries specialize in similar goods. Chiquiar and Ramos-Francia (2009) calculate correlations between indices of revealed comparative advantage for Mexico and for other developing countries. Mexico’s ranking of goods by revealed comparative advantage is most strongly correlated with Hungary, followed by in close order by Thailand, the Philippines, Korea, Turkey, Poland, and China. They find further that in the last decade Mexico has been losing comparative advantage vis-à-vis China in around $40 \%$ of its manufacturing exports (including electrical machinery, computers and electronics, furniture, and non-metallic minerals), while maintaining a comparative advantage in another third of its products (including automobiles and auto parts, industrial machinery, and beverages). Hanson and Robertson (2010) use results from a gravity model of trade to estimate the change in demand for Mexico’s exports that would have occurred had China’s export supply capacity remained constant over the period 1995 to 2005. For Mexico, nullifying the improvement in China’s export capability would mean a $2 \%$ to $4 \%$ increase in the global demand for Mexico’s exports, an effect that is larger than for any other manufacturing oriented developing economy. ${ }^{7}$ Hsieh and Ossa (2010) take a more theoretical approach, introducing Ricardian productivity differences into a Melitz (2003) model of trade, deriving comparative statics for changes in wages and prices resulting from productivity changes in different countries, calibrating the model to data, and then calculating the counterfactual income levels that would have obtained had productivity growth in China over 1993-1994 to 2004-2005 been zero. Not surprisingly, slower productivity growth in China means higher real incomes in

\footnotetext{
${ }^{7}$ The comparison countries are Hungary, Malaysia, Pakistan, the Philippines, Poland, Romania, Sri Lanka, Thailand, and Turkey.
} 
Mexico. Had China's productivity been flat, Mexico's welfare would have been $0.8 \%$ higher, a larger effect than for any other economy that Hsieh and Ossa consider.

Aside from effects on the level of income in Mexico, could competition from China explain Mexico’s lackluster economic growth? If so, the argument would go as follows. Since the late 1980s, China has been undergoing a transition from a rural economy dominated by state owned enterprises to an urban and more market-oriented one. The transition is protracted, as it involves moving over a 150 million workers from the countryside to cities, importing foreign technology, opening China's markets to the rest of the world, and allowing private firms to replace the state in production. China's size, high rate of growth, and increasing outward orientation mean that its emergence is surely changing international prices, improving the terms of trade for countries that produce its importables and deteriorating the terms of trade for countries that produce its exportables. Mexico fits squarely in the latter camp, whereas Argentina, Brazil, Chile, Colombia, and Peru fit in the former. Nevertheless, the downward pressure on the price of Mexico's export goods is unlikely to be permanent. It will abate once China completes its transition or accumulates enough human and physical capital to graduate from the cone of diversification that Mexico now occupies and to move to a cone specializing in more skill and capital intensive products, a process which may already be underway. The impact of China on Mexico, then, is not about long run growth but a prolonged transitional period in which China has been realizing its latent comparative advantage.

The main problem with the China hypothesis for Mexico's growth record is timing. In Figure 2, it is apparent that competition from China became most acute after 2001, suggesting China may have had only a modest role in Mexico’s slow growth in the 1980s and early 1990s. While China's continued rise may be not good news for Mexico, it cannot be the sole factor 
behind Mexico’s performance over the last three decades.

\section{Final discussion}

Any discussion of growth and development in Mexico ends up resembling a Diego Rivera mural, overstuffed with historical characters that collide in repeated and unexpected ways. Mexico's underperformance is overdetermined. The faulty provision of credit, persistence of informality, control of key input markets by elites, continued ineffectiveness of public education, and vulnerability to adverse external shocks each may have a role in explaining Mexico’s development trajectory over the last three decades. We do not yet know the relative importance of these factors for the country's growth record.

Perhaps what is most striking about Mexico's recent experience is that the country has tried so hard but achieved so little. The breadth and depth of reform in the country is astounding, yet Mexico does not have much to show for it. Going forward, one would hope that future research would focus on providing guidance to policy makers about which specific policy interventions may be effective. One can imagine individual research agendas to estimate the impact of changes in bankruptcy provisions, social insurance programs, anti-monopoly regulations, government regulation of electricity markets, or public education on industrial or regional productivity. Such research would undoubtedly be of use to Mexican policy makers. But there is a danger in focusing exclusively on individual policies and ignoring their interactions. Even a cursory examination of Mexico's economic structure suggests the country is deep in the world of the second best, meaning that models based on a single distortion may be a poor guide to how future reform would change economic outcomes in the country.

An example from the discussion in this paper helps drive the point home. Bankruptcy 
provisions that are overly protective of borrowers inhibit the flow of credit to individuals whose observable characteristics suggest they are poor credit risks. The high rate of return to investment in small-scale enterprises suggests that credit market imperfections impede productive investments. Yet, the high rate of return to capital exists in small-scale enterprises that other data suggest have very low TFP and whose survival depends in part on evading payroll taxes that formal sector firms do not escape. If the distortions that cause informality are maintained, reforming bankruptcy provisions could be counter-productive in that it would shift investment towards the country's least productive establishments. If one wants to consider reforming bankruptcy provisions in Mexico, one should also seek to understand how these provisions interact with social insurance programs that may promote informality. Research, then, would benefit from proceeding along two tracks, one that performs rigorous microeconomic analysis of individual policy interventions and another that uncovers the general equilibrium interactions of these policies. 


\section{REFERENCES}

Aspe, Pedro. 1993. Economic Transformation the Mexican Way. Cambridge, MA: MIT Press.

Aydemir, Abdurrahman, Borjas, George J. 2007. "A comparative analysis of the labor market impact of international migration: Canada, Mexico, and the United States." Journal of the European Economic Association, 5(4): 663-708.

Barros, Rodrigo. 2008. "Wealthier but Not Much Healthier: Effects of a Health Insurance Program for the Poor in Mexico.” Mimeo, Stanford University.

Beck, Thorsten, Asli Demirguc-Kunt, and Vojislav Maksimovic. 2005. "Financial and Legal Constraints to Growth: Does Firm Size Matter?” Journal of Finance, 60(1): 137-177

Bergin, Paul, Robert C. Feenstra, and Gordon H. Hanson. 2009. "Offshoring and Volatility: Evidence from Mexico’s Maquiladora Industry,” American Economic Review, 99: 1664-1671

Bergoeing, Raphael, Patrick J. Kehoe, Timothy J. Kehoe, Raimundo Soto. 2002. “A Decade Lost and Found: Mexico and Chile in the 1980s." Review of Economic Dynamics, 5: 166205.

Brambilla, Irene, Amit Khandelwal, and Peter Schott. 2010. "China's Experience under the Multifiber Arrangement (MFA) and the Agreement on Textiles and Clothing (ATC).” In Robert Feenstra and Shang Jin Wei, eds., China's Growing Role in World Trade, Chicago: University of Chicago Press and the NBER.

Chiquiar, Daniel, and Gordon Hanson. 2005. "International Migration, Self-Selection, and the Distribution of Wages: Evidence from Mexico and the United States," Journal of Political Economy, April 113: 239-281.

Chiquiar, Daniel, and Ramos-Francia. 2009. "Competitiveness and Growth of the Mexican Economy.” Banco de Mexico Working Paper No. 2009-11.

Cole, Harold L., Lee E. Ohanian, Alvaro Riascos, and James A. Schmitz, Jr. 2005. "Latin America in the Rear View Mirror.” Journal of Monetary Economics, 52: 69-107.

Collier, Paul. 2007. The Bottom Billion: Why the Poorest Countries Are Failing and What Can Be Done about It. Oxford: Oxford University Press.

de Soto, Hernando. 1989. The Other Path: The Invisible Revolution in the Third World. New York: Harper \& Row.

Dornbusch, Rudiger, and Alejandro Werner. 1994. "Mexico: Stabilization, Reform and No Growth.” Brookings Papers on Economic Activity, 1: 253-315.

Edwards, Sebastian. 2009. “Latin America’s Decline: A Long Historical View.” NBER Working Paper No. 15717. 
Edwards, Sebastian, Gerardo Esquivel, and Graciela Marquez. 2007. The Decline of Latin American Economies. Chicago: University of Chicago and NBER.

Easterly, William. 2002. The Elusive Quest for Growth. Cambridge, MA: MIT Press.

Enright, Michael J., Edith E. Scott, and David Dodwell. 1997. The Hong Kong Advantage. Hong Kong: Oxford University Press.

Fan, Wei, and Michelle White. 2003. "Personal Bankruptcy and the Level of Entrepreneurial Activity.” Journal of Law and Economics, 46(2): 543-568.

Feenstra, Robert C. and Gordon H. Hanson. 2005. "Ownership and Control in Outsourcing to China: Estimating the Property Rights Theory of the Firm,” Quarterly Journal of Economics, May 120: 729-762.

Garcia-Verdu, Rodrigo. 2007. "Demographics, Human Capital and Economic Growth in Mexico, 1950-2005.” Mimeo, The World Bank.

Gropp, Reint, John Karl Scholz, and Michelle White. 1997. "Personal Bankruptcy and Credit Supply and Demand.” Quarterly Journal of Economics, 112(1): 217-251.

Guerrero, Isabel, Luis Felipe Lopez-Calva, and Michael Walton. 2009. "The Inequality Trap and Its Links to Low Growth in Mexico.” In Santiago Levy and Michael Walton, eds., No Growth without Equity? Inequality, Interests, and Competition in Mexico. Washington, DC: Palgrave MacMillan and the World Bank, 111-156.

Haber, Stephen. 1991. "Industry Concentration in Capital Markets: A Comparative Study of Brazil, Mexico, and the United States, 1830-1930.” Journal of Economic History, 51(3): 559-580.

Haber, Stephen. 2005. "Why Institutions Matter: Banking and Economic Growth in Mexico.” Mimeo, Stanford University.

Haber, Stephen. 2009. "Why Banks Do Not Lend: The Mexican Financial System.” In Santiago Levy and Michael Walton, eds., No Growth without Equity? Inequality, Interests, and Competition in Mexico. Washington, DC: Palgrave MacMillan and the World Bank, 283-320.

Hanson, Gordon. 2006. "Illegal Migration from Mexico to the United States," Journal of Economic Literature, 44: 869-924.

Hanson, Gordon. 2010. "Sources of Export Growth in Developing Countries.” Mimeo, UC San Diego.

Hanson, Gordon, and Raymond Robertson. 2010. "China and the Manufacturing Exports of Other Developing Countries," in Robert Feenstra and Shang Jin Wei, eds., China’s Growing Role in World Trade, Chicago: University of Chicago Press and the NBER, 137-159. 
Hsieh, Chang Tai, and Ralph Ossa. 2010. “A Global View of Productivity Growth in China.” Mimeo, University of Chicago.

Jones, Charles. 1995. “R\&D Based Models of Economic Growth.” Journal of Political Economy, 103(4): 759-784.

Juarez, Laura. 2008. “Are Informal Workers Compensated for the Lack of Fringe Benefits? Free Health Care as an Instrument for Formality.” Mimeo, ITAM.

Kaestner, Robert, and Ofer Malamud. 2010. "Self Selection and International Migration: New Evidence from Mexico.” NBER Working Paper No. 15765.

Knox, Melissa. 2008. “Health Insurance for All: An Evaluation of Mexico’s Seguro Popular Program.” Mimeo, University of Washington.

Kuczynski, Pedro-Pablo, and John Williamson. 2003. After the Washington Consensus: Restoring Growth and Reform in Latin America. Washington, DC: Institute for International Economics.

La Porta, Rafael, and Andrei Schleifer. 2008. "The Unofficial Economy and Economic Development.” Brookings Papers on Microeconomic Activity, 1.

Levy, Santiago. 2008. Good Intentions, Bad Outcomes: Social Policy, Informality, and Economic Growth in Mexico. Washington, DC: Brookings Institution Press.

Levy, Santiago, and Michael Walton. 2009. “Equity, Competition and Growth in Mexico.” In Santiago Levy and Michael Walton, eds., No Growth without Equity? Inequality, Interests, and Competition in Mexico. Washington, DC: Palgrave MacMillan and the World Bank, 144.

Lucas, Robert. 1988. “The Mechanics of Economic Growth.” Journal of Monetary Economics. 22(1): 3-42.

Lustig, Nora. 1998. Mexico: The Remaking of an Economy. Washington, DC: Brookings Institution Press.

Manzano, Osmel, and Francisco Monaldi, 2008. “The Political Economy of Oil Production in Latin America.” Economia, 9(1): 59-98.

McKenzie, David, and Hillel Rapoport. 2010. “Can Migration Reduce Educational Attainment? Evidence from Mexico.” Journal of Population Economics, forthcoming.

McKenzie, David, and Christopher Woodruff. 2008. "Experimental Evidence on Returns to Capital and Access to Finance in Mexico.” World Bank Economic Review, 22(3): 457-482.

Moreno-Brid, Juan Carlos, Jesus Santamaria, and Juan Carlos Rivas Valdivia. 2005. "Industrialization and Economic Growth in Mexico after NAFTA: The Road Less Travelled.” Development and Change, 36(6): 1095-1119. 
Mishra, Prachi. 2007. "Emigration and wages in source countries: Evidence from Mexico." Journal of Development Economics, 82(1): 180-199.

Ortiz, Guillermo. 2003. “Overcoming Reform Fatigue.” Finance and Development, September, 14-17.

Pages, Carmen. 2010. La Era de Productividad. Washington, DC: Inter-American Development Bank.

Rajan, R. and Luigi Zingales. 1998. “Financial Dependence and Growth.” American Economic Review, 88: 559-586.

Sokoloff, Kenneth L., and Stanley L Engerman. 2000. "History Lessons: Institutions, Factor Endowments, and Paths of Development in the New World.” Journal of Economic Perspectives, 14(3): 217-232.

Stiglitz, Joseph. 2003. Globalization and Its Discontents. New York: W.W. Norton.

Tornell, Aaron, Frank Westermann, and Lorenza Martinez. 2004. “NAFTA and Mexico’s Less than Stellar Performance.” NBER Working Paper No. 10289. 


\section{FIGURE 1: ECONOMIC GROWTH IN COMPARISON COUNTRIES}

\section{(a) Latin America}

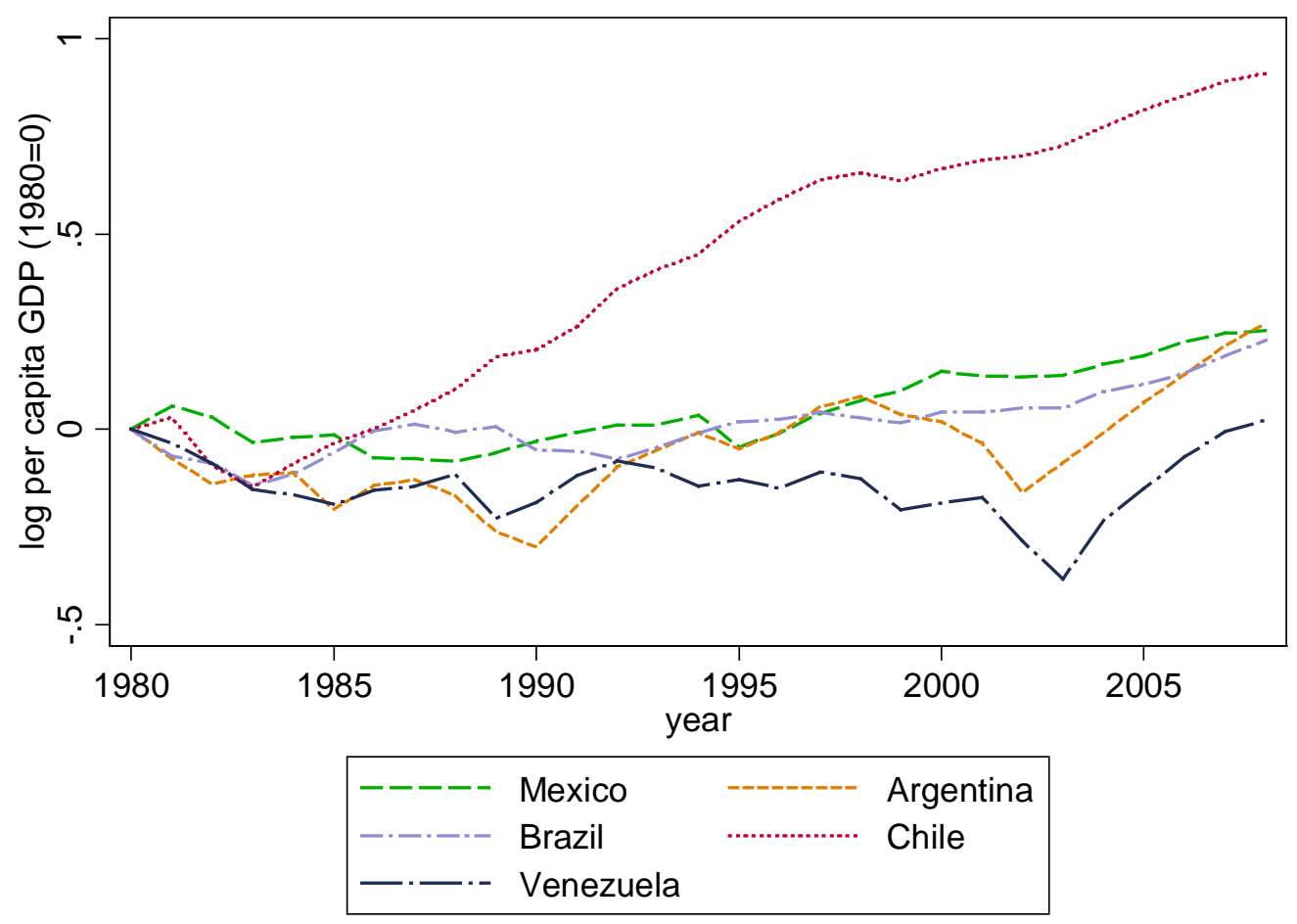

(b) Southeast Asia

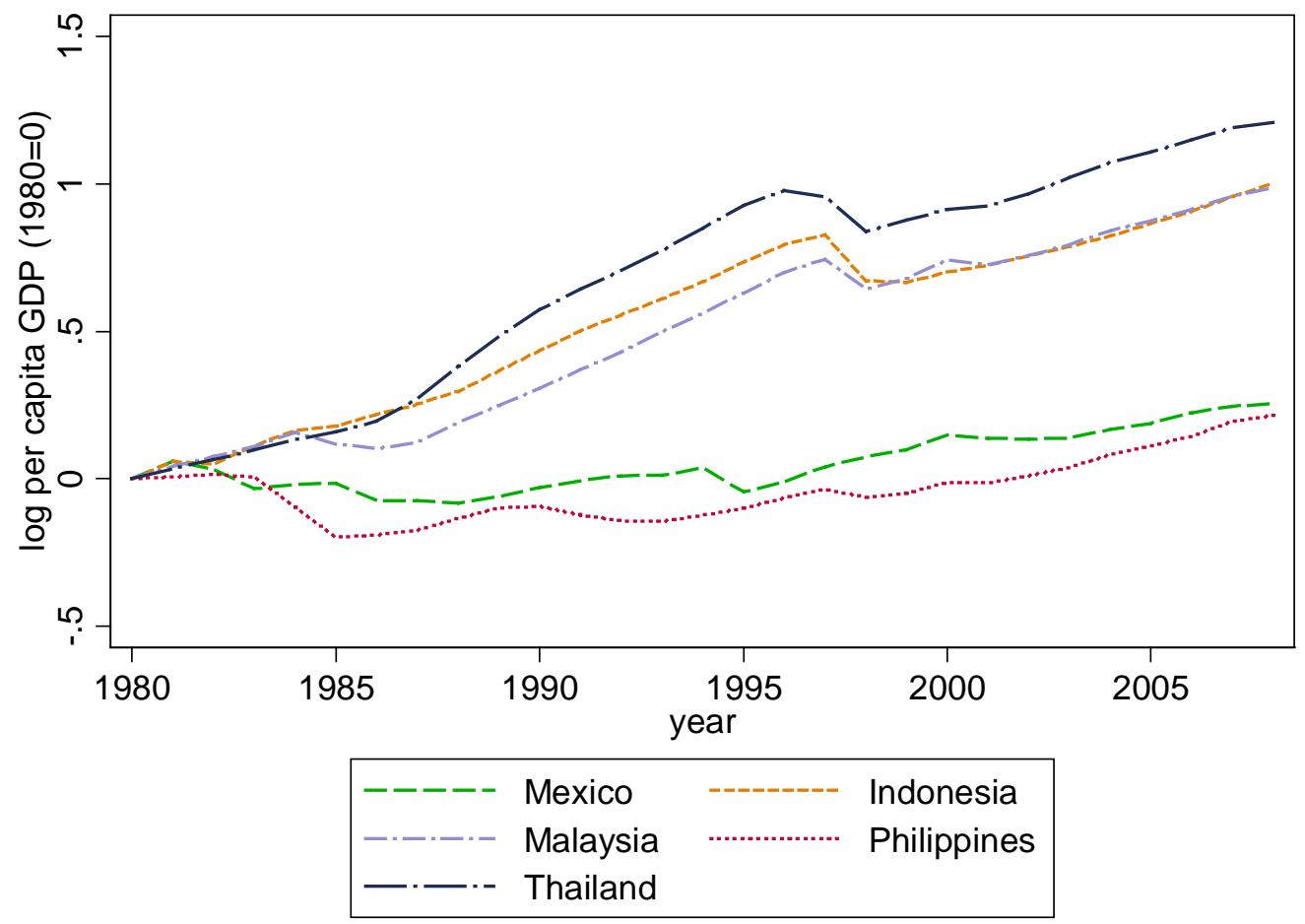




\section{(c) Eastern and Central Europe}

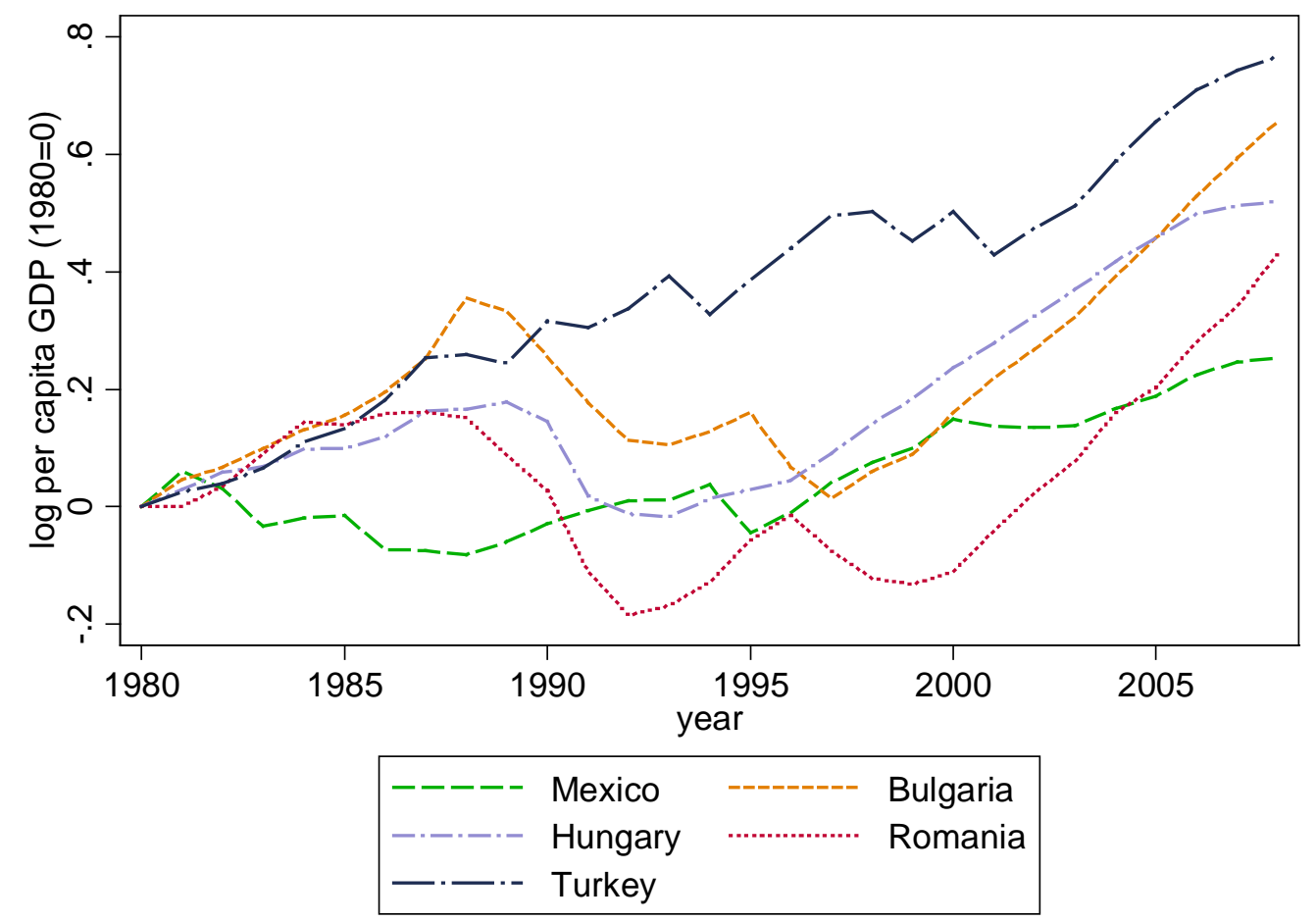


FIGURE 2: SHARE OF US MANUFACTURING IMPORTS

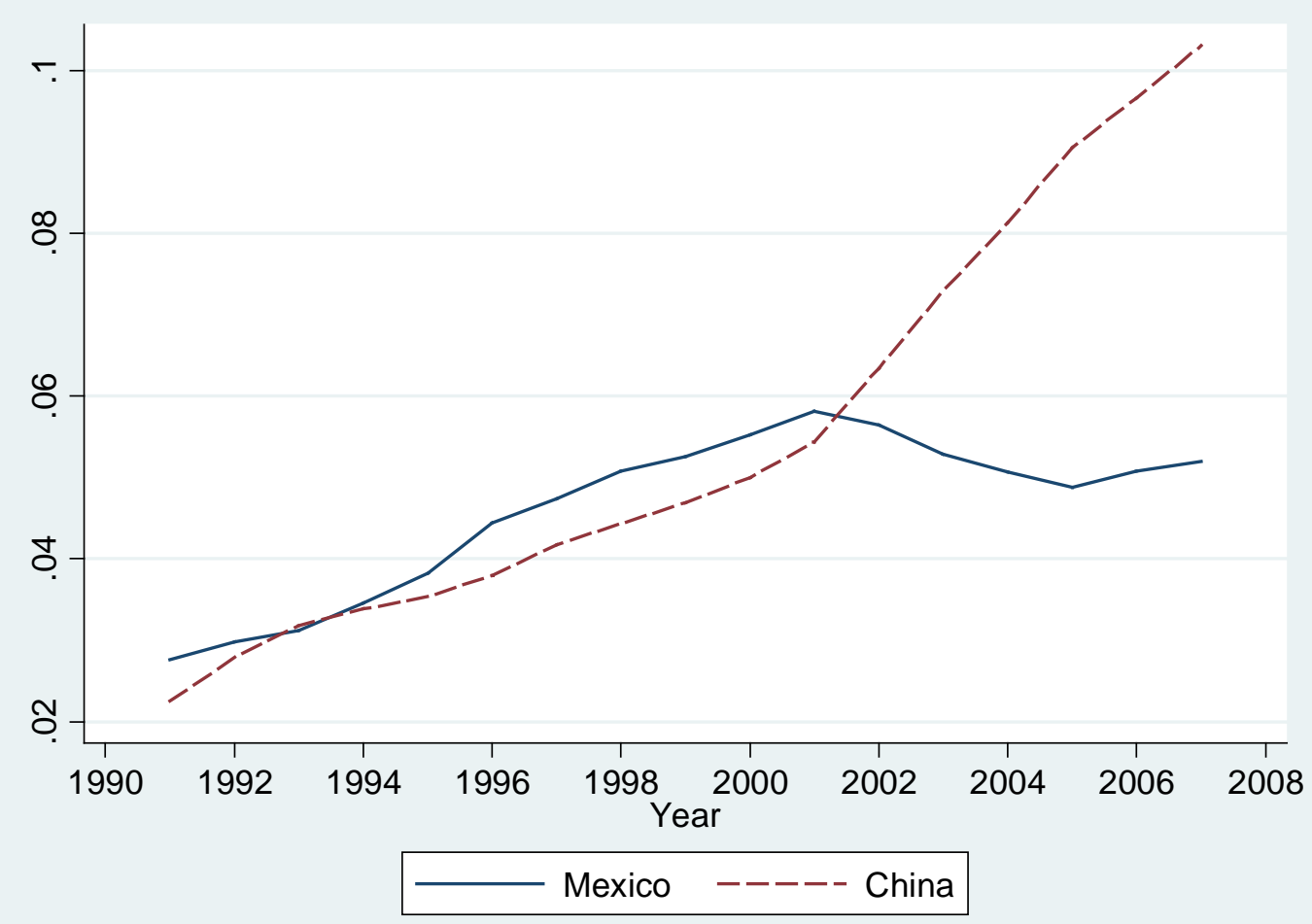


TABLE 1: RATE OF ECONOMIC GROWTH

Average annual change

log per capita GDP

\begin{tabular}{lcc}
\hline Country & $1985-2008$ & $2001-2008$ \\
\hline Argentina & 0.016 & 0.032 \\
Brazil & 0.014 & 0.023 \\
Bulgaria & 0.022 & 0.062 \\
Chile & 0.042 & 0.031 \\
Colombia & 0.019 & 0.031 \\
Czech Republic & 0.020 & 0.040 \\
Hungary & 0.018 & 0.035 \\
Indonesia & 0.035 & 0.038 \\
Malaysia & 0.035 & 0.031 \\
Mexico & 0.011 & 0.013 \\
Peru & 0.015 & 0.044 \\
Philippines & 0.013 & 0.028 \\
Poland & 0.039 & 0.042 \\
Romania & 0.012 & 0.068 \\
Thailand & 0.045 & 0.037 \\
Turkey & 0.027 & 0.033 \\
Venezuela & 0.008 & 0.027 \\
\hline
\end{tabular}


TABLE 2: DOMESTIC CREDIT TO PRIVATE SECTOR (\% OF GDP)

\begin{tabular}{lrr} 
Country & $1991-2000$ & $2001-2008$ \\
\hline \hline Argentina & 20.16 & 13.79 \\
Brazil & 56.42 & 36.89 \\
Colombia & 32.72 & 27.03 \\
Czech Republic & 65.72 & 39.32 \\
Hungary & 27.82 & 49.22 \\
Indonesia & 45.73 & 24.24 \\
Malaysia & 163.44 & 130.94 \\
Mexico & 25.62 & 17.98 \\
Peru & 19.13 & 21.16 \\
Philippines & 42.09 & 33.58 \\
Poland & 21.73 & 32.80 \\
Romania & 9.33 & 20.95 \\
Thailand & 127.55 & 103.01 \\
Turkey & 19.90 & 21.90 \\
Venezuela & 16.93 & 14.63 \\
\hline \hline
\end{tabular}

Notes: Domestic credit to private sector refers to financial resources provided to the private sector, such as through loans, purchases of nonequity securities, trade credits and other accounts receivable. Source: WDI. 